Available online at GSC Online Press Directory

GSC Biological and Pharmaceutical Sciences

e-ISSN: 2581-3250, CODEN (USA): GBPSC2

Journal homepage: https://www.gsconlinepress.com/journals/gscbps

(RESEARCH ARTICLE)

\title{
Propagation spores of arbuscular mycorrhiza fungi and rooting colonization characteristic's on different host plants
}

\author{
Halim 1, ${ }^{*}$, Makmur Jaya Arma 1, Sarawa 1, Tresjia Corina Rakian 1, Muhammad Tufaila 2, Resman 2, \\ Fransiscus Suramas Rembon ${ }^{2}$, Waode Siti Anima Hisein ${ }^{3}$, Syair ${ }^{3}$, Mariadi ${ }^{3}$ and Aminuddin Mane Kandari ${ }^{4}$ \\ ${ }^{1}$ Department of Agrotechnology. Halu Oleo University, Southeast Sulawesi, Indonesia. \\ 2 Department of Soil Science, Halu Oleo University, Southeast Sulawesi, Indonesia. \\ ${ }^{3}$ Department of Plant Protection, Faculty of Agriculture, Halu Oleo University, Southeast Sulawesi, Indonesia. \\ ${ }^{4}$ Department of Environmental Science, Faculty of Forestry and Environmental Science, Halu Oleo University, Southeast \\ Sulawesi, Indonesia.
}

Publication history: Received on 23 June 2019; revised on 11 July 2019; accepted on 16 July 2019

Article DOI: https://doi.org/10.30574/gscbps.2019.8.1.0114

\begin{abstract}
This research aimed to study the propagation spores of arbuscular mycorrhiza fungi (AMF) on different host plants. This research conducted in completely randomized block design (CRBD) with factorial pattern and each treatment was repeated three times and each consist five pot cultures, the total of treatments are 150 pot culture. The first factor are: kinds of host plant (A) with five levels i.e.: Pueraria javanica $\left(\mathrm{A}_{1}\right)$, Centrocema pubescens $\left(\mathrm{A}_{2}\right)$, Sorgum bicolor $\left(\mathrm{A}_{3}\right)$, Cajanus cajan $\left(\mathrm{A}_{4}\right)$, Zea mays $\left(\mathrm{A}_{5}\right)$ and second factor are mycorrhyza fungi $(\mathrm{B})$ which comprises two levels i.e.: Glomus sp ( $\left.\mathrm{B}_{1}\right)$, Acaulospora sp (B2. The result of research showed that the highest average of spores number on $P$. javanica + Glomussp as 38 spores and lowest on C. pubescens+ Glomus sp and Z. mays + Glomus sp respectively as 28 spores. The percentage of roots colonization for Glomus sp on kinds of host plant i.e.: P. javanica as 60.36\%, S. bicolor as $47.93 \%, Z$. mays as $35.36 \%$, C. cajan as $21.72 \%$, C. pubescens as $20.55 \%$. The percentage of roots colonization for Acaulospora sp on S. bicolor as $39.83 \%$, C. cajan as $27.98 \%$, C. pubescens as $26.57 \%$, P. javanica as $23.82 \%$, Z. mays as $21.20 \%$. The highest average weight of shoots and roots on treatment of $P$. javanica $\left(\mathrm{A}_{1}\right)$ each $0.82 \mathrm{~g}$ and $0.91 \mathrm{~g}$.
\end{abstract}

Keywords: Acaulospora sp; Glomus sp; Host plants; Root colonization; Spores abundance

\section{Introduction}

The arbuscular mycorrhiza fungi is one of the potential biological natural resources which are found in nature and can be found in various ecosystems. [1], the genus of mycorrhiza fungi i.e.: Glomus sp, Gigaspora sp, Acalauspora sp and Scutellospora sp. According to [2], the plant on the surface of the earth estimated as $80-90 \%$ to forming a symbiotic mutualism with the mycorrhiza fungi. According [3], the genotypic and species diversity of mycorrhiza fungi are broadly comparable across space.

The mycorrhiza fungi can be an alternative technology of forest and agricultural land rehabilitation, where the application is made possible by the use of local mycorrhiza fungi suitable with host plants to be introduced. [4], reports that's the effort that can be done is by utilizing the plant as a host of mycorrhiza fungi propagation and to increase the spores of mycorrhiza fungi needs to consider the supporting factors so that the results obtained can be optimal. According to [5], the factors that influence the mycorrhiza fungi's occupation are the maturity level of spores, host plants and the environment. [6], states that the selection of host plant is very influential on the production of spores and mycorrhiza infections or colonization in rooting host plants. It is similar to [7], that the abundance of

\footnotetext{
${ }^{*}$ Corresponding author

E-mail address: haliwu_lim73@yahoo.co.id
}

Copyright (C) 2019 Author(s) retain the copyright of this article. This article is published under the terms of the Creative Commons Attribution Liscense 4.0 
arbuscular mycorrhiza fungi in the roots was related to some chemical and physical properties of the soil, thus suggesting an effect of arbuscular mycorrhiza fungi on improving the soil quality.

The host plants preferably by mycorrhizal fungi are capable of providing maximal symbiotic and colonization responses [8]. The criteria of host plant used as mycorrhiza fungi culture are: tolerant to grow in greenhouse conditions, have extensive roots suitable for the development of mycorrhiza fungi [9]. The kinds of host plant using for mycorrhiza fungi propagation or spores production are Pueraria javanica[1], Centrocema pubences, Sorghum bicolor [10], Cajanus cajan [11], maize [12], [13] and some kinds of weed like as Eupatorium odorata, Imperata cylindrica [14], Amaranthus gracilis, Sida rhombifolia [15], and Ageratum conyzoides [16]. The mycorrhiza fungi can be an alternative technology of forest and agricultural land rehabilitation, where the application is made possible by the use of mycorrhiza fungi suitable with host plants to be introduced. According to [17], that's arbuscular mycorrhiza fungi inoculation overall produces positive outcomes on plant production in both controlled and open field conditions, mainly due to several nutrition related benefits that this class of soil fungal symbiosis is able to provide to their host plant. The characteristic infection of mycorrhiza fungi to host plant rooting can be recommended for propagation mycorrhiza fungi.

\section{Material and methods}

\subsection{Preparation of planting media}

The zeolite (1-2 mm in size) using as carrier of mycorrhiza fungi spores was cleaned with sterile water to eliminating the fine powder. Prior to weaning, the surface of the zeolite filled culture pot is covered with paper to reduce the direct contact of the medium with the outside air. The seeds of the host plant used first are seeded in a sprout vessel ( $30 \mathrm{~cm} \times 35 \mathrm{~cm}$ in size) separately. After the leaves appear, the sprouts are ready to be weaned into the culture pot.

\subsection{Study area and experimental setup}

Present study was conducted in Laboratory of Faculty of Forestry and Environmental Science Halu Ole University, Kendari Indonesia. This research conducted in completely randomized block design (CRBD) with factorial pattern and each treatment was repeated three times and each consist five pot cultures, the total of treatments are 150 pot culture. The first factor are: kinds of host plant (A) with five levels i.e.: Pueraria javanica $\left(\mathrm{A}_{1}\right)$, Centrocema pubescens $\left(\mathrm{A}_{2}\right)$, Sorghum bicolor $\left(\mathrm{A}_{3}\right)$, Cajanus cajan $\left(\mathrm{A}_{4}\right)$, Zea mays $\left(\mathrm{A}_{5}\right)$ and second factor are mycorrhyza fungi $(\mathrm{B})$ which comprises two levels i.e.: Glomus sp ( $\left.\mathrm{B}_{1}\right)$, Acaulospora sp ( $\left.\mathrm{B}_{2}\right)$.

\subsection{Preparation of pot culture and application mycorhhiza fungi}

The making of pot culture refers tomethods recommended by [1], with stages:(1) mycorrhiza fungi spores were placed on petrisdish as 10 spores, (2) seedlings of host plants inoculated with mycorrhiza fungi by putting sprouts in the planting hole, then sprayed with 10 spores of mycorrhiza fungi on each planting hole, then closed and watered.

\subsection{Observation of variables}

The variable were observated in this research include: (a) characteristic of mycorrhiza fungi (b) spores number, (c) percentage root colonization was calculated with formula proposed by [18].

Percentage root colonization $=\frac{\text { field of root view invected }}{\text { Total of root view }} \times 100 \%$, (d) root weight $(e)$ shoot weight.

\subsection{Data analysis}

Data of each variable were observed were analyzed by variance of analysis. If the value of $F$ count is greater than the value of F table, then continued with Duncan Multiple Range Test (DMRT) at 95\% confidence level. 


\section{Result and discussion}

Table 1 Recapitulation of the variance effect host plant and mycorrhiza fungi on the observation variable

\begin{tabular}{llll}
\hline Variable & Treatments & & \\
\cline { 2 - 4 } & Host Plant (A) & Mycorrhyza Fungi (B) & Interaction (A*B) \\
\hline Number of spores & ns & ns & ns \\
Root colonization & ns & ns & ns \\
Root weight & $\mathrm{s}$ & ns & ns \\
Shoot weight & $\mathrm{s}$ & $\mathrm{ns}$ & $\mathrm{ns}$ \\
\hline & \multicolumn{2}{c}{ Notes: ns = no significant, s = significant }
\end{tabular}

The treatment of host plant and type of mycorrhiza fungi no significant to alls the observations variable in the independent of treatment and interaction between host plant and mycorrhiza fungi, but host plant significant to root and shoot weight.

\subsection{Number of spores and root colonization}

Table 2 Effect of host plants and mycorrhiza fungi to spores number and root colonization

\begin{tabular}{|c|c|c|c|}
\hline Treatments in Combination & $\begin{array}{l}\text { Number of Spores } \\
\text { (Spores/50 g soil*) }^{*}\end{array}$ & $\begin{array}{l}\text { Average of } \\
\text { Colonization }(\% *)\end{array}$ & Root \\
\hline Pueraria javanica + Glomus sp & 38 & 60.36 & \\
\hline Pueraria javanica + Acaulospora sp & 31 & 23.82 & \\
\hline Centrocema pubescens + Glomussp & 28 & 20.55 & \\
\hline Centrocema pubescens + Acaulospora sp & 29 & 26.57 & \\
\hline Sorghum bicolor + Glomus sp & 33 & 47.93 & \\
\hline Sorghum bicolor + Acaulospora sp & 32 & 39.83 & \\
\hline Cajanus cajan + Glomus sp & 30 & 21.72 & \\
\hline Cajanus cajan + Acaulospora sp & 31 & 27.98 & \\
\hline Zea mays + Glomus sp & 28 & 35.36 & \\
\hline Zea mays + Acaulospora sp & 35 & 21.20 & \\
\hline
\end{tabular}

The highest of spores number on treatment of $P$. javanica + Glomus $\mathrm{sp}$ as 38 spores and lowest on treatment of $C$. pubescens + Glomus sp and Z. mays + Glomus sp respectively as 28 spores. It is indicated that Glomus sp suitable in $P$. javanica plants. According to [19], effects of arbuscular mycorrhiza fungi inoculation on plant growth in soils from organic farm varied depending on the plants species and the nutrient status of the soil. The variation difference of spore number each mycorrhizal fungi on different host plants is thought to be due to the difference in the mycorrhizal fungi response to the host plant. It is similar with result of research from [20], that's number of spores varied with the host plant i.e: peanut, maize and sorghum. [21], states that the root exudates of host plants greatly affect the germination of spores.

Table 2 showed that's on general colonization of mycorrhizal fungi at the root of the host plant is highest in the treatment of P. javanica + Glomus sp as $60.36 \%$ and lowestat the treatmentof . pubescens + Glomus sp as $20.55 \%$. The root infected by Glomus sp according the kind of host plant i.e.:P. javanica as $60.36 \%$, S. bicolor as $47.93 \%$, Z. mays as $35.36 \%$, C. cajan as $21.72 \%$, C. pubescens as $20.55 \%$. Whereas the root colonization for Acaulospora sp on the $S$. bicolor as $39.83 \%$, C. cajan as $27.98 \%$, C. pubescens as $26.57 \%$, P. javanica as $23.82 \%$, Z. mays as $21.20 \%$. Thus then, the Glomus sp is more suited to the P. javanica, whereas the Acaulospora sp is more suited to theS. bicolor.In this study the percentage of mycorrhizal fungi infections at the roots of host plants varies. It is similarity with [22], that's characteristics of root surface besides the anatomical structure of the roots may also influence the early stages of the plant-fungus interaction. 
The compatibility of mycorrhiza fungi and host plant can affect the ability of mycorrhizal fungi to assist the plant in absorbing phosphorus nutrients. This is appropriate statement to [23], root colonization was influenced by the kind of mycorrhizal fungi, host plant species for propagation media and environmental factors. According [5], that's the combination of host plant and kind of mycorrhiza fungi can be evaluated to obtain the best host growth stimuli, root colonization and sporulation. The indicators used as a sign of mycorrhizal fungi infections in rooting host plants are spores, vesicles and arbuscular [15].

The presence of spores in the roots of host plants allegedly associated with the development of mycorrhiza fungi so rapidly that if there is competition in obtaining root exudates then the less competitive to form self-defense in the form of resting spore. [24], that's the vesicles serve as food storage reserves. The arbuscular are not found in the root tissue of host plants because the age of the observed host plat is old in line with the age of the host plant, so that the arbuscula is no longer formed.[25], the arbuscular generally begin to form about 2 to 3 days after the roots are infected.

\subsection{Weight of root and shoot}

Table 3 Effect of host plant to average of root and shoot weight

\begin{tabular}{lll}
\hline Treatments & Average of Roots Weight (g) & Average of Shoots Weight (g) \\
\hline Pueraria javanica (A1) & $0.82^{\mathrm{a}}$ & $0.91^{\mathrm{ab}}$ \\
Centrocema pubescens (A2) & $0.79 \mathrm{ab}$ & $0.86^{\mathrm{b}}$ \\
Sorgum bicolor (A3) & $0.74^{\mathrm{b}}$ & $0.81^{\mathrm{c}}$ \\
Cajanus cajan (A4) & $0.73^{\mathrm{b}}$ & $0.79^{\mathrm{c}}$ \\
Zea mays (A5) & $0.72^{\mathrm{b}}$ & $0.73^{\mathrm{d}}$ \\
& $2=0.06$ & $2=0.34$ \\
DMRT 95\% & $3=0.07$ & $2=0.36$ \\
& $3=0.07$ & $3=0.38$ \\
& $4=0.07$ & $4=0.38$ \\
\hline Notes: The numbers are followed by the same letters in the same column, no significant based DMRT at 95\% confidence level.
\end{tabular}

The highest average of root weight at the treatment of $P$. javanica $\left(\mathrm{A}_{1}\right)$ is not significantly different with treatment of $C$. pubescens $\left(\mathrm{A}_{2}\right)$, but significantly different with the treatment of S. bicolor $\left(\mathrm{A}_{3}\right)$, C. cajan $\left(\mathrm{A}_{4}\right)$ and $Z$. mays $\left(\mathrm{A}_{5}\right)$. The average height root weight for P. javanica allegedly affected directly by Glomus sp. The highest average shoot weight of the host plant is in the treatment of $P$. javanica $\left(\mathrm{A}_{1}\right)$ which is significantly different with treatment of $C$. pubescens $\left(\mathrm{A}_{2}\right)$, S. bicolor $\left(\mathrm{A}_{3}\right)$, C. cajan $\left(\mathrm{A}_{4}\right)$ and Z. mays $\left(\mathrm{A}_{5}\right)$.

The result of research showed that's Glomus sp gives the highest average weight of the roots and shoot of $C$. pubescens (Table 3). It was indicated that between P. javanica and Glomus sp a match occurs, so that the relationship can run optimally mutualism. [13], stated that the higher dependence on mycorrhiza plants, the percentage increase in dry weight also higher. The selection of host can give good results in increasing spore production [1] and the role of host at the initial stage of infection is to provide root exudates to accelerate the rupture of the gastric tube spores of mycorrhizal fungi [26]. At a later stage of development the root exudates is exploited by the mycorrhizal fungi as a carbon source and the contribution of the mycorrhizal fungi is to help the absorption and supply of nutrients and water [27].

The host affects the colonization and sporulation of mycorrhizal fungi through root system and root exudates. The exudates is an organic compound in the form of liquid metabolites that stimulate spore germination, activate fungi transpiration and promote the growth of hyphae and root colonization [28]. According to [29], the characteristics and number of root exudates compounds emitted depend on plant species, plant age and environmental conditions of plant growth.

\section{Conclusion}

From the results of this research, the following conclusions can be drawn: (a) the highest average spore number is treatment of $P$. javanica + Glomus sp as 38 spores and lowest at the treatment of $C$. pubescens + Glomus $\mathrm{sp}$ and Z. mays + Glomus sp respectively as 28 spores. (b) The root colonized by Glomus sp based on the host plant species i.e.P. javanica as $60.36 \%$, S. bicolor as $47.93 \%$, Z. mays as $35.36 \%$, C. cajan as $21.72 \%$, and C. pubescens as $20.55 \%$. (c) The percentage of root colonized by Acaulospora sp on the S. bicolor as 39.83\%, C. cajan as $27.98 \%$, C. pubescens as $26.57 \%$, P. javanica as $23.82 \%$, and Z. mays as $21.20 \%$. (d) The highest average of root and shoot of host plant at the 
treatment of $P$. javanica $\left(\mathrm{A}_{1}\right)$ respectively as $0.82 \mathrm{~g}$ and $0.91 \mathrm{~g}$. The use of $P$. javanica as fungi mycorrhiza propagation is very effective to be developed in the long term, because the kinds of plants also function as ground cover plants, erosion prevention as well as sources of soil organic matter.

\section{Compliance with ethical standards}

\section{Acknowledgments}

The authors would like to thank to the Ministry of Research, Technology and Higher Education of the Republic of Indonesia for the financial assistance through the scheme of National Strategy Research in 2018 with contract number: SP DIPA-042.06.1.401516/2018 December 05, 2017. The authors also thank to the Rector of Halu Oleo University, Dean of Agriculture Faculty and the Chairman of the Research Institute of Halu Oleo University for serviced an administrative.

\section{Disclosure of conflict of interest}

The authors declared that present study was performed in absence

\section{References}

[1] Brundrett M, Bougher N, Dell B, Grove T, and Malajczuk. (1996). Working with mycorrhizas in forestry and agriculture. Australian Centre for International Agricultural Research Mohograph, 372-374.

[2] Smith SE and Read DJ. (1997). Mycorrhizal Symbiosis. Second Edition. Academiz Press. Harcourt Brace \& Company Publisher. London.

[3] Hazard C, and Johnson D. (2007). Does genotypic and species diversity of mycorrhizal plants and fungi affect ecosystem function? Tansley Insight. New Phytologist, 1-7.

[4] Halim, Karimuna L, Rembon FS, Resman and Supriatun T. (2016a). Growth and potential of goat weed (Ageratum conyzoides L.) as host plant for propagation of mycorrhiza fungi. Open Access Library Journal, 3(e2640), 2-8.

[5] Gunawan AW. (2003). Mikoriza Arbuskula. Pusat Antar Universitas Ilmu Hayat. Institut Pertanian Bogor. Indonesia.

[6] Bakhtiar Y. (2002). Selection of vascular mycorrhiza (VAM) fungi. Host plants and spore numbers for producing inoculum. J. Biosains and Bioteknologi Indonesia, 2(1), 36-40.

[7] Casazza G, Lumini L, Ercole E, Dovana F, Guerrina M, Arnulfo A, Minuto L, Fusconi, A and Mucciarelli M. (2017). The abundance and diversity of arbuscular mycorryzal fungi are linked to the soil chemistry of screes and to slope in the Alpic paleo-endemic Berardia subacaulis. PLOS ONE, 12(2), e0171866.

[8] Bagyaraj DJ. (1992). Ecology of Vesicular-arbuscular mycorrhizae. Hand Book of Applied Mycology. Soil and Plants. New York, Marcel Dekker.

[9] Irianto RSB. (2009). The technique of producing arbuscular mycorrhizal fungi Glomus etunicatum in sorghum and pueraria plants. Forest Research and Development Center and Nature Conservation. Balitbang Kehutanan Ministry of Forestry. Bogor.

[10] The technique of producing arbuscular mycorrhizal fungi Glomus etunicatum in sorghum and pueraria plants. Forest Research and Development Center and Nature Conservation. Balitbang Kehutanan Ministry of Forestry. Bogor, 6(1), 83-87.

[11] Prematuri R and Faiqoh N. (1999). Production of arbuscular mycorrhizal fungi inoculum. Forest Biotechnology Laboratory, Biotechnology PAU IPB. Bogor.

[12] Sieverding E. (1991). Vesicular-arbuscular mychorrhyza management in tropical agrosystems. Technical Cooperation Federal Republic of Germany. Eschborn.

[13] Halim, Arma MJ, Rembon FS and Resman. (2015). Impact of mycorrhiza fungi from grassland rhizosphere and liquid organic fertilizer to the growth and yield of sweet corn on Ultisols in South Konawe, Indonesia. International Journal of Agriculture, Forestry and Fisheries, 4(5), 209-215. 
[14] Halim, Arma MJ, Karimuna L, Rembon FS and Resman. (2016). Effect of mycorrhiza fungi propagules and bokashi fertilizer combination to weed density, growth and yield of maize (Zea mays L.) on marginal dry land in Regency of Kendari, Indonesia. International Journal of Development Research, 6(9), 9568-9575.

[15] Halim. (2009). The role endomycorrhiza indigenous of Imperata cylindrica (L.) Beauv and Eupatorium odorata (L.) in weed and corn competitive. (Dissertation). Padjadjaran University, Bandung. Indonesia, 52-128.

[16] Halim, Rembon FS, Kandari AM, Resman and Sani A. (2014). Characteristics of indigenous mycorrhiza of weeds on marginal dry land in South Konawe, Indonesia. International Journal of Agriculture, Forestry and Fisheries, 3(6), 459-463.

[17] Halim, Supriatun T, Karimuna L, Hasid R, Rembon FS and Mariadi. (2016). Impact of mycorrhiza fungi isolated from weed plants on growth of pepper plant seedling (Piper nigrum L.) and incidence of stem rot desease (Phytophthora capsici) in Net House Treatment. International Journal of Current Research, 8(05), 3141931426.

[18] Berruti A, Lumina E, Balestrini R and Bianciotto V. (2016). Arbuscular mycorrhiza fungi as natural biofertilizer: Let's benefit from past success. Frontier in Microbiology, 6, 1559.

[19] Mosee B. (1981). Vesicular-arbuscular mychorrhyza research for tropical agriculture. Res. Bull. 194. Hawaii Institut for Tropical Agriculture.

[20] Kim SJ, Eo JK, Lee EH, Park H and Eom AH. (2017). Effect of arbuscular mycorrhizal fungi and soil conditions on crop plant growth. Mycobiology, 45(1), 20-24.

[21] Carrenho R, Trufem SFB and Bononi VLR. (2002). Effects of using different host plants on the detected biodiversity of arbuscular mycorrhiza fungi from an agroecosystem. Revita Brasil.Bot, 25(1), 93-101.

[22] Buce M, Rossignol M, Jauneau A, Ranjeva R and Beacard G. (2000). The presymbiotic growth of arbuscula mycorrhizal fungi is induced by a branching factor partially purified plant root exudates. Mol. Plant. Nederlands Institute of Ecology.

[23] Brundrett, M and Kendrick, B. (1990). The root and mycorrhizas of herbaceous woodland plant. II. Structural Aspects of Morphology. New Phytologist, 114, 469-479.

[24] Sancayaningsih RP. (2005). The effects of single and dual inoculations of arbuscular mycorhhizal fungi on plant growth and the EST and MDH enzyme profiles of maize roots (Zea mays L.) Grown on Limited Growth Media (Dissertation). UGM. Yogyakarta.

[25] Brundrett M. (1999). Arbuscular Mycorrhizas. CSIRO Forestry and Forest Products.

[26] Barea JM. (1991). Vesicular-arbuscular mycorrhizas as modifiers of soil fertility. Adv. Soil Science.

[27] Juge C, Samson J, Bestien C, Vierheilig H, Coughlan A and Pieche Y. (2002). Breaking dormancy in spores of the arbuscular mycorrhizal fungus Glomus intraradies. A critical cold storage period. Journal of Mycorrhiza, 12, 3742.

[28] Goltapeh EM, Danesh, Prasad, YR and Varma A. (2008). Mycorrhizal Fungi. Genetic and molecular biology, EcoFunction, Biotechnolgi. Eco-Physiology. Springer-Verlag. Berlin Heidenberg.

[29] Pearson VG, Tollot M and Seddas PMA. (2009). Dissection of genetic cell programs driving early arbuscular mycorrhiza interactions, in Aguilar CA, Barea JM and Pearson VG.(eds). Mycorrhizas. Functional Process and Ecological Impact. Springer. Verlag Berlin Heidelberg, 33-45.

[30] Rao NS. (1994). Soil Microorganisms and Plant Growth. Second Editions. University of Indonesia Publisher. Jakarta.

\section{How to cite this article}

Halim, Makmur JA, Sarawa, Tresjia CR, Muhammad T, Resman, Fransiscus SR, Waode SAH, Syair, Mariadi and Aminuddin MK. (2019). Propagation spores of arbuscular mycorrhiza fungi and rootings colonization characteristic's on different host plants. GSC Biological and Pharmaceutical Sciences, 8(1), 78-83. 